\title{
CMV and transfusions, an old story that's not quite over yet
}

\section{Krishna G Badami}

New Zealand Blood Service, Christchurch, New Zealand

Correspondence: Krishna G Badami New Zealand Blood Service,

87 Riccarton Road, Christchurch 80II, New Zealand

Tel +6433439052

Fax +6433439061

Email krishna.badami@nzblood.co.nz
This article was published in the following Dove Press journal:

International Journal of Clinical Transfusion Medicine

10 May 2014

Number of times this article has been viewed

Abstract: Cytomegalovirus (CMV), or human herpes virus 5, can cause a serious infection in immunocompromised patients. Primary infection can be vertical or horizontal - the latter includes transfusion-transmitted CMV (TT-CMV). The immune response against CMV involves both innate (eg, natural killer cells) and adaptive (humoral and cell-mediated) immunity. Through elaborate immune evasion mechanisms, CMV manages to stay latent, mainly in myeloid blood cells. T lymphocytes are mainly responsible for maintaining latency and preventing reactivation. In otherwise healthy individuals, the CMV infection is mild or subclinical. In immunocompromised patients (but also others), primary or reactivated CMV infection can cause significant disease. In addition to direct effects, a range of indirect effects - inflammatory, vasculopathic, etc - can be caused. Some of the indirect effects of CMV may be important even in immunocompetent but ill individuals. In immunocompromised patients, prophylaxis - either universal prophylaxis or preemptive treatment using antiviral drugs, such as ganciclovir against CMV - may be appropriate. The treatment of established CMV infection normally employs the same drugs. The role of intravenous immunoglobulin or CMV-specific hyperimmune globulin in prophylaxis and treatment is uncertain. New anti-CMV drugs, T-cell immunotherapy, and a vaccine are all being developed. From a transfusion medicine perspective, it is important to have a certain background knowledge of CMV, including: an understanding of its epidemiology; the immune response to it; and its clinical features. More specific areas of interest are blood donor selection using methodologies such as routine serology and, possibly, nucleic acid testing, to identify those who pose significant risks of TT-CMV. What are the ways of preventing TT-CMV even from potentially infective donors? The answer may, potentially, be achieved through leukoreduction and pathogen reduction technology.

Keywords: cytomegalovirus, transfusion, infection, Herpesviridae, reactivation, transfusion medicine, leucoreduction

\section{Introduction}

Human cytomegalovirus (CMV) or human herpes virus 5 is of interest to transfusion medicine because it is transmissible through blood and because of the potential consequences of infection - both transfusion-transmitted CMV (TT-CMV) and reactivation of infection - in a variety of patients. These patients include those who are immunocompromised, critically ill, simple transfusion recipients, or combinations of these. Also, the study of CMV provides insights into certain areas, such as immunology, immunotherapy, and vaccine development, likely to interest transfusion medicine professionals.

Apart from factors that are obviously relevant to transfusion medicine, such as ways to prevent TT-CMV, this review discusses other aspects of CMV - its history, 
characteristics, epidemiology, and the clinical features of infection. The immune response to CMV, laboratory diagnosis, and treatment are also discussed briefly. Background material such as this is essential for a proper appreciation of the topic as it pertains to the speciality.

\section{Brief history}

German workers in the late 19th century first observed CMV infection, though it was not recognized as such. Initial reports described large intranuclear inclusions in postmortem tissues. In 1925, Von Glahn and Pappenheimer first postulated that these inclusions might be the result of a viral infection. In the mid-20th century, these inclusions were seen in the cells from living patients. The term "cytomegalic inclusion disease" was coined, and electron microscopy of the inclusions showed that it was a virus. ${ }^{1,2}$

In 1957, CMV was cultured from a patient who was suspected to have toxoplasmosis, the protozoal infection that also causes cytomegalic inclusion disease. Also, in the 1950s, a complement fixation test for the antibody to CMV was developed. Using this, several aspects of the epidemiology of CMV infection were worked out. CMV infection was found to be not only much more prevalent than believed, but it was also found that antibodies to CMV persisted lifelong and that the vast majority of infected individuals were asymptomatic.

From the 1970 s, the increasing numbers of patients immunocompromised following solid organ transplantation (SOT), stem cell transplantation (SCT), or human immunodeficiency virus infection/acquired immunodeficiency syndrome (HIV/AIDS) provided insights into the links between immune status and clinical CMV disease.

In the 1990s, pharmacological anti-CMV treatments started to be developed. In the last decade, adoptive immunotherapy and other experimental treatments for CMV are under investigation. These have followed a better understanding of how CMV infects the cells and mechanisms by which it stays latent and evades the immune system. These topics are well discussed by $\mathrm{Ho}^{1}$ and by Boeckh and Geballe. $^{2}$

From a transfusion medicine perspective, the fact that blood can transmit CMV has long been known. ${ }^{3-5}$ Initially, CMV-safe blood meant donations from CMV-seronegative individuals. Because many adverse events related to transfusion, such as alloimmunization, febrile reactions, and TT-CMV, are due to the presence of white blood cells (WBC) in the transfusion, bedside (ie, poststorage) leucoreduction (LR) was introduced in the 1970s.
Prestorage LR (a more effective method) was introduced in the 1990s. LR-blood is considered to be at least as CMVsafe as that from CMV-seronegative individuals.

\section{Biology of CMV}

CMV is a double-stranded DNA virus and a member of the Herpesviridae family with characteristics, such as latency, common to them. From inside to outside, there is the DNA core enclosed within the nucleocapsid, that is surrounded by the protein tegument that is enclosed within a lipid bilayer membrane that incorporates a number of glycoproteins $(\mathrm{g})$, (namely, gB, gH, gL, gM, gN, and gO). Tegument proteins, the most abundant of which is phosphoprotein 65 , have structural and host immunomodulatory roles. The glycoproteins in the membrane are important for viral attachment and host cell penetration and are the targets for the host's humoral immunity. ${ }^{7}$

CMV primarily infects mucosal epithelial cells. Then, dissemination to monocytic and other hemopoietic cells occurs where it remains latent, likely in myeloid lineage cells. The entry of CMV into host cells involves an initial interaction between CMV glycoproteins like $\mathrm{gB}$ and $\mathrm{gH}$ and a cell surface receptor, such as the platelet-derived growth factor $\alpha$. Following entry, the nucleocapsid is uncoated and inserted into the nucleus. The CMV immediate-early genes 1 and 2 are activated, leading to the replication of viral DNA and capsid assembly in the nucleus. After the new nucleocapsid egresses from the host cell nucleus, secondary coating with virally-encoded, host cell endoplasmic reticulum/Golgi complex-synthesized tegument proteins and membrane glycoproteins takes place before release of intact virus from the cell.

Later, the differentiation of the monocytic precursors to macrophages results in productive infection. Virus is processed by professional antigen-presenting cells, such as dendritic cells (DC). Antigen presentation to T-cells leads to the development of cytolytic T-cells and, through T-B cooperation, the development of humoral immunity. Furthermore, activation of DC, and natural killer (NK) cells, through Toll-like receptors leads to the secretion of cytokines, such as interferons (IFN) $\alpha$ and $\beta$ which activate innate immunity. ${ }^{6}$

\section{Epidemiology of CMV}

Infection comes from close contact with infectious individuals. Transmission can be vertical (transplacental from mother to fetus) or horizontal (through sexual intercourse or contact with fluids, such as saliva, urine, maternal genital 
secretions, breast milk, or blood). It is also transmissible through SCT or SOT.

CMV seroprevalence in adults varies between countries from about $50 \%$ to nearly $100 \%{ }^{7}$. Seroprevalence is higher in lower socioeconomic groups, in females, and in older individuals. ${ }^{8}$ It is significantly higher in high-risk groups, such as male homosexuals. ${ }^{9}$ In developing countries, infection is usually acquired early; whereas, this occurs later in developed countries. Infection is lifelong. CMV stays latent in undifferentiated monocytes and is widespread in the body. Because they affect the proportion of potentially infectious donors, these epidemiological characteristics are important in transfusion medicine. CMV seroprevalence among blood donors is variable and, though a self-selected group, seroprevalence in the group tends to reflect that in the population at large.

\section{Immunity to CMV}

The immune response to CMV is complex. Briefly, both innate and adaptive immunity are involved. ${ }^{10}$ Discussion of the immune response to CMV would be incomplete without briefly discussing ways in which CMV survives the immune challenge and maintains latency.

The main effector cell in innate immunity is the NK cell. IFN $\alpha / \beta$ protect against viral infection in several ways. They prevent the infection of uninfected cells. They activate host cell genes responsible for enzymes that prevent translation of the viral genome and another which degrades viral mRNA. Furthermore, the IFN $\alpha / \beta$ recruit more NK and other cells, activate them, and upregulate the expression of major histocompatibility molecules (MHC) on infected cells, making them susceptible to attack by these cells. ${ }^{11}$

Therefore, human CMV - through Toll-like receptors induces the secretion of IFN $\alpha / \beta$ by NK cells and DC, further activating innate immunity. There is indirect and direct clinical evidence for the role of NK cells in CMV infection. For instance, the NK cell activity increases during both primary infection and reactivation episodes postrenal transplant. ${ }^{12}$ It has been shown that the phenotype (activating or inhibitory) of killer cell immunoglobulin-like receptors and the C-type lectin receptors - the NK cell surface molecules that regulate its effector function - determine the incidence of CMV infection postrenal transplant. ${ }^{13}$ Finally, the NK cell deficiency has been associated with severe CMV infection. ${ }^{14}$

The antibody, alone or with complement, can neutralize free virus. Thus, the entry of CMV into the host cells and the cell-to-cell spread is prevented. The antibody can also act against virus-infected cells, both via complement-mediated lysis of infected cells or through antibody-dependent cellular cytotoxicity mediated by NK cells, macrophages, and neutrophils. ${ }^{10}$

Though the window period using nucleic acid testing (NAT) may be considerably shorter, antibodies to CMV may take 4-8 weeks to develop. IgM anti-CMV antibodies are initially produced, followed by IgG, which persists lifelong. Their absence usually indicates a CMV-naive subject. The antigens targeted are primarily $\mathrm{gB}$ and $\mathrm{gH}^{6}$ but also the products of the UL128, UL130, and UL131A genes. ${ }^{2}$ There is some evidence - both from animal and human studies - that antibodies to CMV may provide protection against reactivation. ${ }^{15,16}$ Furthermore, seropositivity usually indicates the presence of cell-mediated immunity (CMI) to CMV and vice-versa. ${ }^{17}$ There is some evidence that passive prophylaxis with anti-CMV antibodies can protect against infection in susceptible patients. ${ }^{18,19}$

However, neither polyvalent nor hyperimmune CMV intravenous immunoglobulin appears effective as passive prophylaxis against CMV infections post-SCT. ${ }^{20}$

The viral proteins produced and processed in the host cell cytoplasm are exhibited on the surface of infected cells in the peptide-binding cleft of ubiquitous, and highly polymorphic, class I MHC molecules. If the interaction between T-cell receptor and viral peptide-MHC class I complex is high affinity, this may result in T-cell activation. ${ }^{10}$

$\mathrm{CD} 8+, \mathrm{CD} 4+$, and $\gamma \delta \mathrm{T}$ lymphocytes all appear to play important roles in the long-term control of CMV. There is an association between specific depletion of these T-cells and the reactivation of CMV or CMV disease. ${ }^{21-24}$ Reconstitution of these subsets has beneficial effects on CMV infection. ${ }^{25-27}$ Though CD8+ T-cells play the key role in the CMI against $\mathrm{CMV}^{28}$ interestingly, CD4+ T-cells that are considered to play mainly supportive roles in CMI and humoral immunity have themselves been shown to have cytolytic activity against $\mathrm{CMV}^{29}$

A feature of the CD8+ T-cell response to CMV is the oligoclonality that gradually develops with specificities covering a few immunodominant CMV epitopes. Also, with increasing age, the proportion of this oligoclone increases in contrast to what happens with the $\mathrm{CD} 8+\mathrm{T}$-cell response to other viruses - a phenomenon known as "memory inflation." The memory inflation of CMV-specific CD8+ T-cell clones may be to the detriment of the immune response to other pathogens. The CD8+ T-cell clones involved in memory inflation have phenotypic and functional characteristics typical of T-cells of the effector-memory type, particularly in that they express CD45RA (hence being referred to as 
TEMRA) and secrete antiviral cytokines and are capable of cell lysis. ${ }^{6,30}$

\section{Immune evasion by CMV}

$\mathrm{CMV}$ has evolved multiple strategies to evade the variety of immune responses against it and to maintain latency. CMV latency and reactivation are important considerations in transfusion medicine. It is neither possible nor necessary to cover all these mechanisms exhaustively in this review. A brief outline of the salient features will be provided; the interested reader is referred to three recent reviews of the subject. ${ }^{31-33}$

Certain terms need to be defined. Latency is described as a situation where there is evidence of "viral DNA in tissues without transcription or translation of lytic or 'late' gene RNAs to protein and thereby absence of lytic virus. Reactivation" is the "recovery of infectious virus following some period of viral latency." 34

There is evidence for CMV latency in both mice and humans. ${ }^{34,35} \mathrm{CMV}$ may go latent directly without productive infection or expressing any genes connected with it. Alternatively, a phase of productive infection may be followed by latency.

The examination of the CMV genes expressed during latency reveals that the full set - particularly, those necessary for viral replication - is not expressed. Additionally, there are genes that are expressed only during or just prior to latency and the products of those genes help to maintain that state.

Among the methods CMV uses to evade host immunity are antigenic variations ${ }^{36,37}$ that: block the presentation of CMV antigens by host cell MHC molecules; produce partial human IFN homologs that are predominantly immunosuppressive; and code for certain glycoproteins that prevent host IgG-fragment crystallizable region receptor binding, infected host cell apoptosis, IFN synthesis, and CMI. ${ }^{38-43}$

\section{Consequences of CMV infection and relationship between immunity and clinical effects}

Infection in the fetus (congenital CMV infection) may be severe and may cause thrombocytopenia and petechiae, liver function abnormalities, hepatosplenomegaly, intrauterine growth retardation, microcephaly, retinitis, and hearing loss. The IgM anti-CMV (of fetal origin since the maternal IgM cannot cross the placenta) may be found in the baby at birth. However, the severity of the infection is variable. Severe disease is more likely to follow the primary infection in a CMV-naive pregnant woman than reactivation of the infection in CMV-seropositive mothers who will, incidentally, form the majority in many countries. It is worth noting here that the consequences of primary CMV infection in neonates - including sick or preterm neonates (the groups mostly likely to require transfusions) - are unclear. ${ }^{44}$

Between 1.6\%-3.7\% of exposed, CMV-naive, pregnant women acquire primary CMV infection. ${ }^{45}$ However, even in CMV-seropositive pregnant women, the primary infection with a different strain of CMV can occur. ${ }^{46}$ Of primary $\mathrm{CMV}$ infections in pregnant women, 30\%-40\% will result in fetal infection, compared to $1 \%$ following the reactivation of previous maternal infection. Overall, about $10 \%$ of babies with congenital CMV infection are symptomatic. ${ }^{47}$ Since pregnant women can acquire primary infection through means other than transfusion (for instance, contact with young children who are excreting CMV in their urine), other hygiene measures may be required in this group.

Fetal infection - especially following primary maternal infection - may have serious consequences and acceptable treatments for CMV are unavailable in this setting. Because LR blood may still permit CMV transmission (though the risk is small), it may be prudent to use transfusions that are not only from CMV-seronegative donors but are also LR - at least for elective transfusions during pregnancy and for fetal transfusions even though these are rarely required. ${ }^{48}$

Infection in well-immunocompetent subjects, including children, may remain subclinical or, at worst, result in a mild illness (mononucleosis syndrome similar to that caused by the Epstein-Barr virus, another human herpes virus), characterized by pharyngitis, myalgia, fever, and sometimes mild hepatosplenomegaly, lymphadenopathy, and atypical lymphocytes in the blood. ${ }^{49,50}$

In immunocompromised subjects, infection can have serious consequences. Those at greatest risk are those with impaired CMI, such as fetuses, premature, sick, or low birthweight infants, those undergoing SCT, SOT, or certain other treatments, and individuals with HIV-AIDS.

Among such patients, CMV infections can occur in those who are CMV-naive or those in whom initially asymptomatic infection is reactivated. CMV is a cytopathic virus and infection - either primary or reactivation - and in the immunocompromised can affect many tissue systems. Pneumonitis, gastroenteritis, retinitis, hepatitis, etc, are all well described. In these patients, primary infections are usually more severe than reactivations. This is an important point in transfusion medicine.

In allo-SCT, the highest risk of CMV disease is in CMV-seropositive patients followed by CMV-naive patients 
receiving a CMV-seropositive SCT (donor [D]+recipient $[\mathrm{R}]-\mathrm{SCT})$. The proportions of this and other combinations will vary with CMV seroprevalence in different populations. In allo-SCT patients, the severity of chronic graft versus host disease (GVHD) - through immunosuppression, and perhaps some of the indirect effects discussed - also affects the risk of CMV infection. Because it may be possible to choose SCT donors based on the CMV serostatus, it may be advantageous to choose $\mathrm{CMV}$-seropositive donors for $\mathrm{CMV}$-seropositive patients $(\mathrm{D}+\mathrm{R}+\mathrm{SCT})$ because of a possible lower risk of $\mathrm{CMV}$ reactivation and CMV-naive donors for CMV-naive patients (D-R-SCT). ${ }^{51}$ With D-R-SCT, the risk of CMV disease is low. In this group, the main threat is posed by blood transfusions. LR is considered sufficient, and CMVseronegative blood is not required for SCT patients. ${ }^{48}$

Patients with hematological or other malignancies receiving conventional chemotherapy or radiotherapy, or patients on immunosuppressants for other reasons, are not immunocompromised enough to be at particular risk. Treatment for chronic lymphocytic leukemia and non-Hodgkin lymphoma with purine analogs (eg, fludarabine) or alemtuzumab (anti-CD52, Campath ${ }^{\circledR}$; Genzyme Corp., Cambridge, USA) that result in very low CD4+ and CD8+ counts, and, possibly, antithymocyte globulin ${ }^{52}$ may be exceptions, but not rituximab (anti-CD20) which affects B-cells. ${ }^{53}$ These patients may develop a range of infections, including CMV. Nevertheless, for patients on all these treatments, including purine analogs or alemtuzumab, standard or LR blood (if universal LR operates) suffices.

With SOT, the highest risk is with the $\mathrm{D}+\mathrm{R}-$ combination. In addition to the serostatus of the patient and the donor, the risk is influenced by the organ transplanted and the degree of immunosuppression. Risk is the highest with lung transplants (because of the load of potentially infected monocytes in the lung, the level of immunosuppression required, and the seriousness of CMV pneumonitis in the transplanted lung), followed by the small intestine and the pancreas. Liver and kidney transplants pose a much lower risk. ${ }^{54}$

In SOT patients, in addition to nonspecific illness with fever, leukopenia, and transaminitis, specific end-organ disease - particularly in the transplanted organ itself - may occur. ${ }^{55}$ One effect of this is the higher risk of allograft rejection in SOT patients with CMV disease than in those without. ${ }^{56}$ The pathophysiology of this allograft rejection appears to be related to $\mathrm{CMV}$-mediated vasculopathy.

Despite the serious consequences of CMV infection, because of the shortage of certain organ donors, CMV serostatus is a secondary concern in the SOT setting. In
SOT, as with allo-SCT, the risk of CMV disease is low with D-R- transplants. Such transplants are a good indication for CMV-safe blood to avoid primary infection. LR is considered sufficient, and CMV-seronegative blood is not required for SOT patients. ${ }^{48,57}$

CMV disease in HIV-AIDS patients is a serious illness. Retinitis and gastrointestinal tract involvement are especially common. Patients who are most likely to be affected are those with low CD4+ counts and high viral loads, conditions that are now likely to be found only in those not on, or those who are unresponsive to, antiretroviral therapy. ${ }^{58}$ Most CMV disease in this group is due to reactivation of infection in previously seropositive individuals. As noted, CMV seroprevalence is very high in some HIV risk groups. LR is sufficient and CMVseronegative blood is not required for HIV-AIDS patients. ${ }^{48}$

Finally, it is increasingly being recognized that CMV, in addition to causing direct cytopathic effects due to active, lytic CMV replication, can - both in its active and latent forms - cause clinically significant and apparently contradictory, immunopathological, and indirect effects. Broadly, these are considered under CMV-related immunosuppressive, autoimmune, inflammatory, and vasculopathic categories. ${ }^{59,60}$

Immunosuppression - related to the methods CMV uses for immune evasion (see "Immune evasion by CMV") together with that secondary to immunosuppressive agents in SOT and SCT patients - may cause superinfections with various bacteria or fungi and is associated with reactivations of other viruses. ${ }^{61-63}$

CMV can trigger autoimmunity. A wide variety of autoimmune conditions and phenomena have been described in association with CMV. These include post-SOT type I (autoimmune) diabetes mellitus, cryoglobulinemia, antiphospholipid antibodies, scleroderma, systemic lupus erythematosus, and cytoplasmic antineutrophil cytoplasmic antibodies-positive vasculitis. ${ }^{64-67}$ Significantly, some of these autoimmune conditions have improved with anti-CMV treatment. ${ }^{68}$ How CMV induces autoimmune phenomena is imperfectly understood. Mimicry by viral proteins of human proteins and polyclonal B-cell activation - directly or indirectly - are among the mechanisms proposed..$^{60}$

Regarding inflammation, it is unclear if CMV replication is its cause, its effect or, if the two are merely coincidental. As an illustration, consider that the CMV replication in myeloid precursors is associated with maturation to macrophages and DC. Cytokines, such as tumor necrosis factor- $\alpha$ and IFN- $\gamma$ from these cells, activate parts of the CMV genome that helps to start viral replication, which leads to further maturation of the host cells that are associated with inflammation. ${ }^{59}$ 
Evidence for the role of CMV in vasculopathy comes from laboratory, epidemiological, and clinical sources. ${ }^{69} \mathrm{It}$ has been shown in SOT that even subclinical CMV infection may lead to chronic endothelial dysfunction in both transplanted organ and systemic vasculature ${ }^{70}$ and may cause increased overall and cardiovascular mortality. ${ }^{71}$ Aggressive, universal, compared to preemptive, CMV prophylaxis postheart transplant ameliorates cardiac allograft vasculopathy. ${ }^{72}$ Mechanisms by which CMV causes vasculopathy involve complex, not fully understood, and apparently contradictory interactions with the host immune system.

Among these are: the activation of the transcription nuclear factor kappa B by CMV entry into host endothelial cells leading to CMV replication in the cell; release of the cytokines by the immune cells following CMV infection leading to upregulation of adhesion molecules and human leukocyte antigen (HLA) II expression on endothelial cells; vessel wall smooth muscle proliferation caused by CMV cytokine homologs; reduced endothelial nitrous oxide synthesis; and inflammatory responses within the graft. The clinical effect of all of this is not only local and systemic vasculopathy, but it is also an increased allograft rejection. ${ }^{69}$

It is now recognized that, through many of the above mechanisms, CMV causes significant adverse effects in critically ill but immunocompetent patients. Temporary immunocompromise may occur during critical illness, and such patients can have CMV reactivations. Equally, it is believed that stress or catecholamines, bacterial sepsis, or other causes of inflammation and WBC in transfusions can trigger reactivations. Also, it is possible that CMV reinfection, through transfusions or other sources, can occur in such patients. Consequences of CMV reactivation or reinfection in such patients include increased mortality, ICU length of stay, mechanical ventilation duration, and acute respiratory distress syndrome. ${ }^{73,34}$

\section{Laboratory features of CMV infection and disease}

The following is not a comprehensive discussion of this topic for which the reader is referred to an excellent review. ${ }^{74}$ Only those points of particular relevance to transfusion medicine will be mentioned here.

The first point is that different definitions apply to CMV infection, disease, and their subcategories. CMV infection is a generic term that covers viremia, antigenemia, DNAemia, RNAemia, and seropositivity. Each of these terms is defined more precisely. In general, demonstrating the virus itself, its antigens, or its nucleic acids - with or without either IgM or IgG
anti-CMV - suggests active infection. "Primary CMV infection" refers to the presence of CMV antibodies in a previously seronegative individual. Reinfection or reactivation is a new CMV infection in a previously infected individual without the virus being detected for at least 4 weeks, despite active surveillance. CMV disease definitions depend on the clinical features that vary with the end organ affected plus, in general, the demonstration of CMV in the organ, tissue, or fluid concerned, by viral culture, histopathology, immunohistochemistry, in situ hybridization, antigenemia (eg, through phosphoprotein 65 assay [pp65 assay]), or polymerase chain reaction (PCR). The last, alone, may be too sensitive to confirm CMV disease in a particular location reliably. ${ }^{55}$ However, quantitative PCR is very useful for another purpose - to estimate the viral load and to determine if a threshold has been reached that would trigger preemptive anti-CMV treatment in SCT or SOT patients (see "Prevention and treatment of severe CMV disease").

The second point is that, with respect to CMV infection, different aims and strategies apply to immunocompromised patients and to immunocompetent individuals, such as blood or organ donors. In the former, the aim post-transplant is to determine if there is an active infection, though serostatus will have been determined pretransplant too. CMV serostatus may be difficult to evaluate in babies because of the passive transfer of maternal anti-CMV and in pretransplant patients because of recent transfusions. Potentially, it may be possible to determine CMV infection status in such patients using CMV-specific T-cell assays. ${ }^{75}$

Patients with active infection are mostly immunocompromised. In them, antibody responses are poor or delayed, and CMV serology has no role. The clinical presentation of active infection, at a given time, varies from asymptomatic to nonspecific illness to significant, specific end organ effects.

In immunocompetent individuals, the aim is to determine if there is a history of infection, estimate time of infection, and so make deductions about infectivity (see "Prevention of CMV transmission through transfusion"). This is done through testing for CMV serostatus. IgM, or low-avidity IgG, anti-CMV indicates primary CMV infection, while highavidity IgG anti-CMV indicates an infection that occurred more than 2-4 months previously. Enzyme-linked immunosorbent assay (ELISA) is the most commonly available test, but immunofluorescence, indirect hemagglutination, and latex agglutination assays are also available. ${ }^{76}$ Validated ELISA has sensitivity $>99.5 \%$ and specificity $>98.1 .^{48}$

Because of the importance of T-cells in CMV control, assays are being developed that help to determine the level 
and functionality of CMV-specific CD4+ and CD8+ T-cells in patients who are post-SOT. This, then, is used to identify at-risk patients and to guide prophylaxis. ${ }^{54,77}$

\section{Prevention and treatment of severe CMV disease}

Apart from general measures, such as CMV-safe blood transfusions (see "Prevention of CMV transmission through transfusion") in at-risk SOT and SCT patients, other prophylactic measures are required to prevent CMV disease secondary to infection originating in either the patient or the transplanted organ or tissue.

Prophylaxis is generally of two types. With universal prophylaxis, antiviral agents, such as acyclovir, valacyclovir, ganciclovir, or valganciclovir, are given to the subgroups of patients at high risk; for example, it is given to SOT or SCT involving the $\mathrm{D}+\mathrm{R}-$ or sometimes $\mathrm{D}+\mathrm{R}+$ combinations to prevent primary or reactivation infection. This approach results in unnecessary treatment for many - increasing toxicity, cost, and viral resistance. On the other hand, the preemptive treatment approach employs regular screening - viral culture, antigenemia assays, or PCR - to determine the level of viremia to predict those at the highest risk of developing CMV disease. At an appropriate viremia threshold, treatment is started with, usually, valganciclovir with the aim of taking viremia level down to a certain target.

Treatment of established CMV disease, such as pneumonitis, retinitis, etc, requires pharmacologic and other treatment, reduction in the level of immunosuppression. Intravenous ganciclovir (or oral valganciclovir, or cidofovir or foscarnet) together with intravenous immunoglobulin or CMV-specific hyperimmune globulin are usually used. ${ }^{51,54,78}$ The role of immunoglobulin, whether pooled or CMV-specific - in addition to ganciclovir for preventing CMV disease - is controversial, especially in SCT. ${ }^{79}$ However, there may be a role for this post-SOT; for instance, there may be a role to reduce some indirect effects, such as allograft rejection and cardiac allograft vasculopathy postheart transplant. ${ }^{80}$

Experimental treatments - drugs such as CMX 001, AIC 246, maribavir, ${ }^{81}$ and adoptive immunotherapy to restore an immunocompromised patient's CMV-specific T-cells - have been subjects of intense study. Problems with adoptive immunotherapy include: time required to generate clinically relevant T-cell expansion in vitro; failure to obtain sustained CD8+ cytotoxic T-lymphocyte responses in vivo without concomitant CMV-specific CD4+ immunotherapy; and concerns about the use of live CMV for generating
CMV-specific T-cells in vitro. Various strategies to overcome these are being developed and are well discussed by Crough and Khanna. ${ }^{6}$

\section{Prevention of CMV transmission through transfusion}

Obviously, the best way of reducing TT-CMV, as with other transfusion-related adverse events, is through conservative transfusion practices. More specifically, the initial method of reducing TT-CMV in high-risk groups was by selecting CMV-naive blood donors. Though this, compared to those receiving standard, unselected blood components, was shown to significantly reduce $\mathrm{CMV}$ infection in two randomized studies (including in D-R-SCT patients) ${ }^{82,83}$ clearly it does not eliminate TT-CMV. One explanation may be infections from seronegative, but potentially infectious, window phase donors.

Indeed, it has been demonstrated that $12 \%-62 \%$ of recent seroconverters had evidence of CMV DNA in plasma, depending on the interval between testing and the last seronegative result; whereas, $0 \%$ of those who had been CMV-seropositive for more than a year had evidence of this. ${ }^{84}$ Though false negative reactions are rare, and the sensitivity of ELISA for CMV is high, they do occur. ${ }^{85-87}$ False negative serological reactions may be due to technical reasons, antigenic heterogeneity in $\mathrm{CMV}^{88}$ or because some individuals are poor antibody responders. It has been known that more than one-half of CMV-seronegative individuals have CMV DNA. ${ }^{89}$

On the other hand, there are individuals who are CMV-seropositive but noninfectious; these may constitute the majority of blood donors. ${ }^{90}$ If CMV-seronegativity is considered the only true marker of CMV-safety, then in countries with high seropositivity rates, there may be a very limited availability of CMV-safe blood donors.

In fact, it has been demonstrated that individuals who are CMV-seropositive but who have latent (ie, not recent) infection mostly do not have CMV DNA detectable in their plasma. ${ }^{84,91}$ In contrast, as noted, some CMV-seronegative individuals (in the window phase) may, in fact, have CMV DNA detectable in their blood.

From the mid-1980s, studies in at-risk (CMV-naive) neonates showed that LR of red blood cell (RBC) transfusions might help to prevent TT-CMV. Of course, reducing TT-CMV was not the sole, or even the main, objective of LR. Many other actual or potential benefits of LR have been described. These include: reduced febrile nonhemolytic transfusion reactions; ${ }^{92,93}$ alloimmunization to HLA and other antigens, 
and - consequently - platelet refractoriness $;{ }^{94-97}$ transfusionrelated immunomodulation that may predispose to viral or bacterial infections and tumor recurrence, ${ }^{98,99}$ possible transfusion-associated GVHD, post-transfusion purpura; ${ }^{100}$ and transfusion-related acute lung injury; ${ }^{101,102}$ and transmission of various blood cell-associated pathogens, ${ }^{103}$ including variant Creutzfeldt-Jakob disease, human $\mathrm{T}$ lymphotropic virus type I, and HIV. ${ }^{104-109}$ The impetus for introducing LR has been varied. In some countries, it was variant CreutzfeldtJakob disease; in others, it was transfusion-related immunomodulation. In yet others, it was overall transfusion safety. ${ }^{110}$

With respect to CMV, reports from the 1980s suggested that frozen-thawed-deglycerolized RBC and salinewashed RBC respectively achieved significant degrees of LR and helped reduce TT-CMV, compared to standard transfusions. ${ }^{11,112}$ Later studies in neonates described the use of LR filters for this purpose. ${ }^{113,114}$

Early LR filters removed 90\%-99\% (1-2 $\left.\log _{10}\right) \mathrm{WBC}$, but the current third and fourth generation filters remove $\geq 99.9 \%$ 99.99\% (3-4 $\left.\log _{10}\right)$ WBC. ${ }^{115}$ Assuming a WBC count in a donor of $5 \times 10^{9} / \mathrm{L}$, a unit of whole blood $(400 \mathrm{~mL})$ will contain about $2 \times 10^{9}$ or $2,000 \times 10^{6} \mathrm{WBC}$. Thus, LR of this unit of whole blood using current filters would leave a residue of $\leq 2 \times 10^{6} \mathrm{WBC}$ or $\leq 0.1 \%$ of the WBC originally in the unit. Currently, in American guidelines, LR means achieving a WBC count of $\leq 5 \times 10^{6}$ with $\geq 85 \%$ RBC recovery in $\geq 95 \%$ of units or, in European guidelines, $\leq 1 \times 10^{6} \mathrm{WBC} /$ unit. $^{116}$ Evidence for these thresholds relates more to the prevention of HLA-alloimmunization and less to preventing TT-CMV.

Direct evidence for the effectiveness of LR in human blood was provided by the study of Dumont et al, ${ }^{117}$ who examined residual levels of CMV DNA by quantitative PCR, following filtration (RBC and platelets) and in apheresis platelets. They found significant reductions (median: 2,400 genome equivalents $/ \mathrm{mL}$ pre-LR to 500 genome equivalents $/ \mathrm{mL}$ post-LR) with, and no significant differences between, the three methods.

Several small studies in at-risk adult patients provided data on the effectiveness of LR for reducing TT-CMV. ${ }^{118-125}$ With the exception of one, these were nonrandomized studies. Patients in the test groups who had hematological malignancies or bone marrow failure were undergoing either conventional therapy or SCT (allo-SCT or auto-SCT) and were given either pre- or poststorage LR blood components. Controls were patients with either the same conditions or nonhematological malignancies, given either unscreened, or CMV-seronegative, blood components.
Furthermore, various CMV diagnostic tests were used, and CMV preemptive treatment was not uniformly given. No definite conclusion can be drawn from these heterogeneous, mostly retrospective, studies other than that they provide some evidence for the utility of LR in reducing TT-CMV in these settings.

In 1995, Bowden et al ${ }^{126}$ reported a landmark trial in which CMV-naive, allogeneic, and autologous SCT patients were randomized to receive either LR or CMV-seronegative blood components. They found no significant difference between the two as far as CMV infection, disease, or overall survival between day 21 and day 100 post-transplant (the time span chosen to avoid including infections acquired prior to the start of the study) were concerned and concluded that the two types of blood component were equivalent. ${ }^{126}$ However, a secondary analysis of events between day 0 and day 100 post-transplant showed that, though infection rates between the two groups was similar, the likelihood of disease in the LR group was higher.

As explanations for this, the authors suggested reactivation of prior but latent infection, filter failure, and the possibility that a higher frequency of repeated family member donations in the LR arm may have exposed patients in that arm to particularly infectious donors.

This study has been criticized on the grounds of: being underpowered to detect a difference between groups transfused with CMV-seronegative components and those given LR components; for including autologous SCT patients who may have been at lower risk of CMV infection and disease; for using bedside filters that may have been a less effective way of LR; for protocol violations that were nevertheless included in the analysis; and for the lack of effective CMV surveillance and preemptive therapy.

Other cautionary notes regarding the effectiveness of LR - at least with respect to TT-CMV - were also struck. First, James et al ${ }^{127}$ suggested that free CMV in plasma, presumably derived from the breakup of white blood cells in storage and not removable by LR, might potentially cause TT-CMV. Up to this point, many of the LR filters in use were bedside filters.

The second was by Nichols et $\mathrm{al}^{124}$ in a report of a nonrandomized study in 2003. They examined 807 CMVnaive SCT patients, in whom the incidence of TT-CMV was assessed weekly, using the phosphoprotein 65 antigenemia assay during two time periods. In one, only CMV-seronegative and/or LR blood components were used; in the second, LR platelets obtained by apheresis without filtration were also used. In these patients, a significantly higher frequency 
of TT-CMV was found in the second, compared to the first, period.

Then, in an overview of the reports by Bowden et al, ${ }^{126}$ Pamphilon et al, ${ }^{123}$ and Nichols et al, ${ }^{124}$ the first two showed that, with respect to TT-CMV, LR blood was equivalent to CMV-seronegative blood; the third showed the opposite, Vamvakas $^{128}$ found that CMV-seronegative blood reduced the risk of TT-CMV by $60 \%$, compared to LR components. However, it included the results of Pamphilon et $\mathrm{al}^{123}$ and Nichols et al where confounding (eg, the group getting LR components was also the group that received the most transfusions) was a significant problem. ${ }^{124}$

Recently, the LR versus CMV-seronegative debate has been reopened. Ziemann et al, ${ }^{129}$ using nucleic acid testing, found that CMV DNA was much more likely to be found in the early seroconversion phase than in either the true window period or in remote seroconverters.

Similarly, Furui et al, ${ }^{130}$ in a study of Japanese blood donors, showed that CMV DNA was most likely to be found in the relatively elderly and in those who were anti-CMV $\mathrm{IgM}+/ \mathrm{IgG}-$ (ie, recent seroconverters). They linked these findings to reactivations of latent infection in older donors. Moreover, they found CMV in the plasma fraction post-LR, like Dollard et $\mathrm{al}^{131}$ who found that another human herpes virus (human herpesvirus 8, which is associated with Kaposi's sarcoma and a few other conditions) could be found cellfree, post-LR.

Therefore, Roback and Josephson ${ }^{132}$ make the point that neither CMV-seronegativity nor LR may provide absolute protection against TT-CMV. Neither does the approach of using stable CMV-seropositive (seropositive $>1$ year) blood donors without $\mathrm{LR}^{84}$ provide this because of potential CMV viremia during reactivations.

They propose four alternative types of components to further reduce the risk of TT-CMV: 1) from CMV-seronegative donors subjected to LR; 2) from CMV-seronegative and CMV NAT-negative donors (without LR); 3) from CMVseronegative and CMV NAT-negative donors subjected to LR; and 4) from CMV NAT-negative donors subjected to LR. While 3) would obviously provide maximal protection, it would also significantly curtail the pool of available donors. They conclude that perhaps 4) may be the best of these four options and wonder if pathogen reduction (PR) may be the way forward, replacing all these various strategies.

$\mathrm{PR}$ is a proactive and more or less global way of dealing with transfusion-transmitted infections, including CMV. Agents such as psoralen S-59 that intercalate pathogen nucleic acids when exposed to ultraviolet light are used. ${ }^{133}$
To quote Vamvakas and Blajchman, ${ }^{134}$ PR would mean that "rather than this agent-by-agent reactive approach, there could be a more all-encompassing approach to blood safety that would address most transfusion-transmitted pathogens ...." PR systems have been demonstrated to be effective against CMV specifically. ${ }^{135}$

In addition to the effect on pathogens, the same agents, because of their effect on nucleic acids in general, are at least as effective as $\gamma$-irradiation against the lymphocytes that may cause transfusion-associated GVHD. ${ }^{136}$ Two RCTs have demonstrated equivalence, if not superiority, of platelet transfusions prepared with PR to standard (LR) platelets with respect to clinical and the laboratory endpoints. ${ }^{137,138}$ One significant drawback of PR is that, currently, they are inapplicable to $\mathrm{RBC}$, meaning that the non-PR methods will continue to be required for $\mathrm{RBC}$ transfusions, making $\mathrm{PR}$ an addition to current measures against transfusion-transmitted infections rather than an outright replacement to them. Other drawbacks include ineffectiveness against prions and certain other pathogens, and some cellular losses that may result in patients having to receive additional transfusions. ${ }^{138}$

Finally, though strictly not belonging in this section, it will be useful to mention vaccines against CMV briefly. These vaccines have been in development for many years, but no licensed product is available yet. Several areas of uncertainty have slowed development. The candidate population - healthy women preconception or patients awaiting SCT or SOT is unclear. Within target populations, it is unclear if those who are CMV-naive, those who are CMV seropositive, or both, should be candidates. Which CMV antigens should be targets? Also, it is uncertain what constitutes immunity is this humoral or cellular immunity or both? Last, how should the vaccine be delivered? Clearly, a desired level of immunity needs to be achieved without causing CMV infection. The interested reader is referred to two recent reviews where these, and related matters, are comprehensively discussed. ${ }^{139,140}$

\section{Conclusion}

CMV has attracted the attention of transfusion medicine professionals for a long time. Our engagement with CMV is far from over. This has provided insights into many fields, especially human immunology. As far as this speciality is concerned, areas likely to be of future interest include: the role of TT-CMV in immunocompetent but ill patients; the further delineation of the role of CMV intravenous immunoglobulin in SOT patients; PR that will be applicable to RBC, in addition to platelets and plasma; and the further development 
and refining of pharmacologic agents that target CMV at the cellular and molecular levels and of vaccines.

\section{Disclosure}

The author has no conflicts of interest in this work.

\section{References}

1. Ho M. The history of cytomegalovirus and its diseases. Med Microbiol Immunol. 2008;197(2):65-73.

2. Boeckh M, Geballe AP. Cytomegalovirus: pathogen, paradigm, and puzzle. J Clin Invest. 2011;121(5):1673-1680.

3. Kantor GL, Goldberg LS, Johnson BL Jr, Derechin, MM, Barnett EV. Immunologic abnormalities induced by postperfusion cytomegalovirus infection. Ann Intern Med. 1970;73(4):553-558.

4. Stevens DP, Barker LF, Ketcham AS, Meyer HM Jr. Asymptomatic cytomegalovirus infection following blood transfusion in tumor surgery. JAMA. 1970;211(8):1341-1344.

5. Lerner PI, Sampliner JE. Transfusion-associated cytomegalovirus mononucleosis. Ann Surg. 1977;185(4):406-410.

6. Crough T, Khanna R. Immunobiology of human cytomegalovirus: from bench to bedside. Clin Microbiol Rev. 2009;22(1):76-98.

7. Krech U. Complement-fixing antibodies against cytomegalovirus in different parts of the world. Bull World Health Organ. 1973;49(1): 103-106.

8. Bate SL, Dollard SC, Cannon MJ. Cytomegalovirus seroprevalence in the United States: the national health and nutrition examination surveys, 1988-2004. Clin Infect Dis. 2010;50(11):1439-1447.

9. Collier AC, Meyers JD, Corey L, Murphy VL, Roberts PL, Handsfield HH. Cytomegalovirus infection in homosexual men. Relationship to sexual practices, antibody to human immunodeficiency virus, and cell-mediated immunity. Am J Med. 1987;82(3 Spec No):593-601.

10. Roitt I, Brostoff J, Male D. Immunology. 6th ed. St Louis: Mosby; 2001.

11. Compton T, Kurt-Jones EA, Boehme EW, et al. Human cytomegalovirus activates inflammatory cytokine responses via CD14 and Toll-like receptor 2. J Virol. 2003;77(8):4588-4596.

12. Venema $H$, van den Berg AP, van Zanten C, van Son WJ, van der Giessen M, The TH. Natural killer cell responses in renal transplant patients with cytomegalovirus infection. J Med Virol. 1994;42(2): 188-192.

13. Hadaya K, de Rham C, Bandelier C, et al. Natural killer cell receptor repertoire and their ligands, and the risk of CMV Infection after kidney transplantation. Am J Transplant. 2008;8(12):2674-2683.

14. Orange JS. Human natural killer cell deficiencies and susceptibility to infection. Microbes Infect. 2002;4(15):1545-1558.

15. Jonjić S, Pavić I, Polić B, Crnković I, Lucin P, Koszinowski UH. Antibodies are not essential for the resolution of primary cytomegalovirus infection but limit dissemination of recurrent virus. J Exp Med. 1994;179(5):1713-1717.

16. Klenovsek K, Weisel F, Schneider A, et al. Protection from CMV infection in immunodeficient hosts by adoptive transfer of memory B cells. Blood. 2007;110(9):3472-3479.

17. Sester M, Gärtner BC, Sester U, Girndt M, Mueller-Lantzsch N, Köhler H. Is the cytomegalovirus serologic status always accurate? A comparative analysis of humoral and cellular immunity. Transplantation. 2003;76(8):1229-1230.

18. Snydman DR, Werner BG, Heinze-Lacey B, et al. Use of Cytomegalovirus Immune Globulin to Prevent Cytomegalovirus Disease in Renal-Transplant Recipients. N Engl J Med. 1987;317(17): 1049-1054.

19. Nigro G, Adler SP, La Torre R, Best AM; Congenital Cytomegalovirus Collaborating Group. Passive immunization during pregnancy for congenital cytomegalovirus infection. N Engl J Med. 2005;353(13): $1350-1362$.
20. Raanani P, Gafter-Gvili A, Paul M, Ben-Bassat I, Leibovici L, Shpilberg O. Immunoglobulin prophylaxis in hematological malignancies and hematopoietic stem cell transplantation [review]. Cochrane Database Syst Rev. 2008;4:CD006501.

21. Reusser P, Riddell SR, Meyers JD, Greenberg PD. Cytotoxic T-lymphocyte response to cytomegalovirus after human allogeneic bone marrow transplantation: pattern of recovery and correlation with cytomegalovirus infection and disease. Blood. 1991;78(5):1373-1380.

22. Widmann T, Sester U, Gärtner BC, et al. Levels of CMV Specific CD4 $\mathrm{T}$ cells are dynamic and correlate with CMV viremia after allogeneic stem cell transplantation. PLoS One. 2008;3(11):e3634.

23. Sester U, Gärtner BC, Wilkens H, et al. Differences in CMV-specific T-cell levels and long-term susceptibility to CMV infection after kidney, heart and lung transplantation. Am J Transplant. 2005;5(6):1483-1489.

24. Déchanet J, Merville P, Bergé F, et al. Major expansion of gammadelta $\mathrm{T}$ lymphocytes following cytomegalovirus infection in kidney allograft recipients. J Infect Dis. 1999;179(1):1-8.

25. Riddell SR, Watanabe KS, Goodrich JM, Li CR, Agha ME, Greenberg PD. Restoration of viral immunity in immunodeficient humans by the adoptive transfer of T cell clones. Science. 1992;257(5067): 238-241.

26. Walter EA, Greenberg PD, Gilbert MJ, et al. Reconstitution of cellular immunity against cytomegalovirus in recipients of allogeneic bone marrow by transfer of T-cell clones from the donor. $N$ Engl J Med. 1995;333(16):1038-1044.

27. Einsele H, Roosnek E, Rufer N, et al. Infusion of cytomegalovirus (CMV)-specific T cells for the treatment of CMV infection not responding to antiviral chemotherapy. Blood. 2002;99(11):3916-3922.

28. Sester M, Sester U, Gärtner BC, Girndt M, Meyerhans A, Köhler H. Dominance of virus-specific CD8 T cells in human primary cytomegalovirus infection. J Am Soc Nephrol. 2002;13(10):2577-2584.

29. Elkington R, Shoukry NH, Walker S, et al. Cross-reactive recognition of human and primate cytomegalovirus sequences by human CD4 cytotoxic T lymphocytes specific for glycoprotein B and H. Eur $J$ Immunol. 2004;34(11):3216-3226.

30. Klenerman P, Dunbar PR. CMV and the art of memory maintenance. Immunity. 2008;29(4):520-522.

31. Goodrum F, Caviness K, Zagallo P. Human cytomegalovirus persistence. Cell Microbiol. 2012;14(5):644-655.

32. Jackson SE, Mason GM, Wills MR. Human cytomegalovirus immunity and immune evasion. Virus Res. 2011;157(2):151-160.

33. Mocarski ES Jr. Immunomodulation by cytomegaloviruses: manipulative strategies beyond evasion. Trends Microbiol. 2002;10(7):332-339.

34. Cook CH, Trgovcich J. Cytomegalovirus reactivation in critically ill immunocompetent hosts: a decade of progress and remaining challenges. Antiviral Res. 2011;90(3):151-159.

35. Kurz S, Steffens HP, Mayer A, Harris JR, Reddehase MJ. Latency versus persistence or intermittent recurrences: evidence for a latent state of murine cytomegalovirus in the lungs. J Virol. 1997;71(4):2980-2987.

36. Steininger C. Clinical relevance of cytomegalovirus infection in patients with disorders of the immune system. Clin Microbiol Infect. 2007;13(10):953-963.

37. Renzette N, Bhattacharjee B, Jensen JD, Gibson L, Kowalik TF. Extensive genome-wide variability of human cytomegalovirus in congenitally infected infants. PLoS Pathog. 2011;7(5):e1001344.

38. Miller DM, Zhang Y, Rahill BM, Waldman WJ, Sedmak DD. Human cytomegalovirus inhibits IFN-alpha-stimulated antiviral and immunoregulatory responses by blocking multiple levels of IFN-alpha signal Transduction. J Immunol. 1999;162(10):6107-6113.

39. Terhune S, Torigoi E, Moorman N, Silva M, Qian Z, Shenk T, Yu D. Human cytomegalovirus UL38 protein blocks apoptosis. J Virol. 2007;81(7):3109-3123.

40. Marshall EE, Geballe AP. Multifaceted evasion of the interferon response by cytomegalovirus. J Interferon Cytokine Res. 2009;29(9):609-619.

41. Slobedman B, Barry PA, Spencer JV, Avdic S, Abendroth A. Virus-encoded homologs of cellular interleukin-10 and their control of host immune function. J Virol. 2009;83(19):9618-9629. 
42. Wilkinson GW, Tomasec P, Stanton RJ, et al. Modulation of natural killer cells by human cytomegalovirus. J Clin Virol. 2008;41(3): 206-212.

43. Hegde NR, Tomazin RA, Wisner TW, et al. Inhibition of HLA-DR assembly, transport, and loading by human cytomegalovirus glycoprotein US3: a novel mechanism for evading major histocompatibility complex class II antigen presentation. J Virol. 2002;76(21): 10929-10941.

44. Luck S, Sharland M. Postnatal cytomegalovirus: innocent bystander or hidden problem? Arch Dis Child Fetal Neonatal Ed. 2009;94(1): F58-F64.

45. Stagno S, Pass RF, Cloud G, et al. Primary cytomegalovirus infection in pregnancy. Incidence, transmission to fetus, and clinical outcome. JAMA. 1986;256(14):1904-1908.

46. Boppana SB, Rivera LB, Fowler KB, Mach M, Britt WJ. Intrauterine transmission of cytomegalovirus to infants of women with preconceptional immunity. $N$ Engl J Med. 2001;344(18): 1366-1371.

47. Kenneson A, Cannon MJ. Review and meta-analysis of the epidemiology of congenital cytomegalovirus (CMV) infection. Rev Med Virol. 2007;17(4):253-276.

48. Advisory Committee on the Safety of Blood, Tissues and Organs. Report of the Cytomegalovirus Steering Group. London: Advisory Committee on the Safety of Blood, Tissues and Organs; 2012. Available from: https://www.gov.uk/government/uploads/system/uploads/attachment_ data/file/215126/dh_132966.pdf. Accessed November 28, 2013.

49. Gandhi MK, Khanna R. Human cytomegalovirus: clinical aspects, immune regulation, and emerging treatments. Lancet Infect Dis. 2004;4(12):725-738.

50. Sissons JG, Carmichael AJ. Clinical aspects and management of cytomegalovirus infection. $J$ Infect. 2002;44(2):78-83.

51. Boeckh M, Ljungman P. How we treat cytomegalovirus in hematopoietic cell transplant recipients. Blood. 2009;113(23):5711-5719.

52. Hassan-Walker AF, Kidd IM, Sabin C, Sweny P, Griffiths PD, Emery VC. Quantity of human cytomegalovirus (CMV) DNAemia as a risk factor for CMV disease in renal allograft recipients: relationship with donor/recipient CMV serostatus, receipt of augmented methylprednisolone and antithymocyte globulin (ATG). J Med Virol. 1999;58(2): 182-187.

53. Sandherr M, Einsele H, Hebart H, et al; Infectious Diseases Working Party, German Society for Hematology and Oncology. Antiviral prophylaxis in patients with haematological malignancies and solid tumours: Guidelines of the Infectious Diseases Working Party (AGIHO) of the German Society for Hematology and Oncology (DGHO). Ann Oncol. 2006;17(7):1051-1059.

54. Kotton CN, Kumar D, Caliendo AM, et al; Transplantation Society International CMV Consensus Group. Updated international consensus guidelines on the management of cytomegalovirus in solid-organ transplantation. Transplantation. 2013;96(4):333-360.

55. Ljungman P, Griffiths P, Paya C. Definitions of cytomegalovirus infection and disease in transplant recipients. Clin Infect Dis. 2002;34(8):1094-1097.

56. Arthurs SK, Eid AJ, Pedersen RA, et al. Delayed-onset primary cytomegalovirus disease and the risk of allograft failure and mortality after kidney transplantation. Clin Infect Dis. 2008;46(6):840-846.

57. Zuk DM, Humar A, Weinkauf JG, Lien DC, Nador RG, Kumar D. An international survey of cytomegalovirus management practices in lung transplantation. Transplantation. 2010;90(6):672-676.

58. Centers for Disease Control and Prevention. Guidelines for prevention and treatment of opportunistic infections in HIV-infected adults and adolescents. Atlanta, GA, USA: Centers for Disease Control and Prevention; 2009. Available from: http://www.cdc.gov/mmwr/preview/ mmwrhtml/rr5804a1.htm Accessed November dd, 2013.

59. Freeman RB Jr. The 'indirect' effects of cytomegalovirus infection. Am J Transplant. 2009;9(11):2453-2458.

60. Varani S, Landini MP. Cytomegalovirus-induced immunopathology and its clinical consequences. Herpesviridae. 2011;2(1):6.
61. Husni RN, Gordon SM, Longworth DL, et al. Cytomegalovirus infection is a risk factor for invasive aspergillosis in lung transplant recipients. Clin Infect Dis. 1998;26(3):753-755.

62. Nichols WG, Corey L, Gooley T, Davis C, Boeckh M. High risk of death due to bacterial and fungal infection among cytomegalovirus (CMV)-seronegative recipients of stem cell transplants from seropositive donors: evidence for indirect effects of primary CMV infection. J Infect Dis. 2002;185(3):273-282.

63. Burak KW, Kremers WK, Batts KP, et al. Impact of cytomegalovirus infection, year of transplantation, and donor age on outcomes after liver transplantation for hepatitis C. Liver Transpl. 2002;8(4):362-369.

64. Fernández EJ, Auyanet I, Guerra R, et al. [Primary cytomegalovirus infection causing a kidney transplant patient to develop cryoagglutinins and cryoglobulins]. Nefrologia. 2010;30(2):267-268. Spanish.

65. Mengarelli A, Minotti C, Palumbo G, et al. High levels of antiphospholipid antibodies are associated with cytomegalovirus infection in unrelated bone marrow and cord blood allogeneic stem cell transplantation. Br J Haematol. 2000;108(1):126-131.

66. Sekigawa I, Nawata M, Seta N, Yamada M, Iida N, Hashimoto H. Cytomegalovirus infection in patients with systemic lupus erythematosus. Clin Exp Rheumatol. 2002;20(4):559-564.

67. Lidar M, Lipschitz N, Langevitz P, et al. Infectious serologies and autoantibodies in Wegener's granulomatosis and other vasculitides: novel associations disclosed using the Rad BioPlex 2200. Ann NY Acad Sci. 2009;1173:649-657.

68. Valderhaug TG, Hjelmesaeth J, Rollag H, et al. Reduced incidence of new-onset posttransplantation diabetes mellitus during the last decade. Transplantation. 2007;84(9):1125-1130.

69. Potena L, Valantine HA. Cytomegalovirus and development of cardiac allograft vasculopathy: evidences and therapeutic implications. Trends in Transplant. 2010;4:108-116.

70. Simmonds J, Fenton M, Dewar C, et al. Endothelial dysfunction and cytomegalovirus replication in pediatric heart transplantation. Circulation. 2008;117(20):2657-2661.

71. Sagedal S, Hartmann A, Nordal KP, et al. Impact of early cytomegalovirus infection and disease on long-term recipient and kidney graft survival. Kidney Int. 2004;66(1):329-337.

72. Potena L, Grigioni F, Magnani G, et al. Prophylaxis versus preemptive anticytomegalovirus approach for prevention of allograft vasculopathy in heart transplant recipients. J Heart Lung Transplant. 2009;28(5):461-467.

73. Limaye AP, Kirby KA, Rubenfeld GD, et al. Cytomegalovirus reactivation in critically ill immunocompetent patients. JAMA. 2008;300(4):413-422.

74. Ross SA, Novak Z, Pati S, Boppana SB. Overview of the diagnosis of cytomegalovirus infections. Infect Disord Drug Targets. 2011;11(5): 466-474.

75. Schmidt T, Ritter M, Dirks J, Gärtner BC, Sester U, Sester M. Cytomegalovirus-specific T-cell immunity to assign the infection status in individuals with passive immunity: a proof of principle. J Clin Virol. 2012;54(3):272-275.

76. cdc.gov [homepage on the Internet]. Cytomegalovirus (CMV) and congenital CMV infection. Centers for Disease Control and Prevention; 2010 [updated December 6, 2010]. Available from: http://www.cdc.gov/ cmv/clinical/lab-tests.html. Accessed November 28, 2013.

77. Gerna G, Lilleri D, Fornara C, et al. Monitoring of human cytomegalovirus-specific CD4 and CD8 T-cell immunity in patients receiving solid organ transplantation. Am J Transplant. 2006;6(10):2356-2364.

78. British Transplantation Society. Guidelines for the Prevention and Management of CMV Disease after Solid Organ Transplantation. Cheshire, UK: British Transplantation Society; 2011. Available from: http://www.bts.org.uk/Documents/Guidelines/Active/Final\%20 CMV\%20Guideline\%20for\%20web\%2012-9-2011.pdf. Accessed November 28, 2013.

79. Raanani P, Gafter-Gvili A, Paul M, Ben-Bassat I, Leibovici L, Shpilberg O. Immunoglobulin prophylaxis in hematopoietic stem cell transplantation: systematic review and meta-analysis. J Clin Oncol. 2009;27(5):770-781. 
80. Potena L, Holweg CT, Chin $\mathrm{C}$, et al. Acute rejection and cardiac allograft vascular disease is reduced by suppression of subclinical cytomegalovirus infection. Transplantation. 2006;82(3):398-405.

81. Price NB, Prichard MN. Progress in the development of new therapies for herpesvirus infections. Curr Opin Virol. 2011;1(6):548-554.

82. Bowden RA, Sayers M, Flournoy N, et al. Cytomegalovirus immune globulin and seronegative blood products to prevent primary cytomegalovirus infection after marrow transplantation. $N$ Engl J Med. 1986;314(16):1006-1010.

83. Miller WJ, McCullough J, Balfour HH Jr, Prevention of cytomegalovirus infection following bone marrow transplantation: a randomized trial of blood product screening. Bone Marrow Transplant. 1991;7(3): 227-234.

84. Ziemann M, Krueger S, Maier AB, Unmack A, Goerg S, Hennig H. High prevalence of cytomegalovirus DNA in plasma samples of blood donors in connection with seroconversion. Transfusion. 2007;47(11): 1972-1983.

85. Booth JC, Hannington G, Bakir TM, et al. Comparison of enzymelinked immunosorbent assay, radioimmunoassay, complement fixation, anticomplement immunofluorescence and passive haemagglutination techniques for detecting cytomegalovirus IgG antibody. J Clin Pathol. 1982;35(12):1345-1348.

86. Taswell HF, Reisner RK, Rabe DE, Shelley CD, Smith TF. Comparison of three methods for detecting antibody to cytomegalovirus. Transfusion. 1986;26(3):285-289.

87. Logan S, Barbara J, Kovar I. Cytomegalovirus screened blood for neonatal intensive care units. Arch Dis Child. 1988;63(7 Spec No): 753-755.

88. Faix RG. Cytomegalovirus antigenic heterogeneity can cause false-negative results in indirect hemagglutination and complement fixation antibody assays. J Clin Microbiol. 1985;22(5):768-771.

89. Larsson S, Söderberg-Nauclér C, Wang FZ, Möller E. Cytomegalovirus DNA can be detected in peripheral blood mononuclear cells from all seropositive and most seronegative healthy blood donors over time. Transfusion. 1998;38(3):271-278.

90. Roback JD, Drew WL, Laycock ME, Todd D, Hillyer CD, Busch MP. CMV DNA is rarely detected in healthy blood donors using validated PCR assays. Transfusion. 2003;43(3):314-321.

91. Drew WL, Roback JD. Prevention of transfusion-transmitted cytomegalovirus: reactivation of the debate? Transfusion. 2007;47(11): 1955-1958.

92. Patterson BJ, Freedman J, Blanchette V, et al. Effect of premedication guidelines and leukoreduction on the rate of febrile nonhaemolytic platelet transfusion reactions. Transfus Med. 2000;10(3):199-206.

93. Pruss A, Kalus U, Radtke H, et al. Universal leukodepletion of blood components results in a significant reduction of febrile non-hemolytic but not allergic transfusion reactions. Transfus Apher Sci. 2004;30(1): 41-46.

94. Eernisse JG, Brand A. Prevention of platelet refractoriness due to HLA antibodies by administration of leukocyte-poor blood components. Exp Hematol. 1981;9(1):77-83.

95. Schiffer CA, Dutcher JP, Aisner J, Hogge D, Wiernik PH, Reilly JP. A randomized trial of leukocyte-depleted platelet transfusion to modify alloimmunization in patients with leukemia. Blood. 1983;62(4): 815-820.

96. McFarland J, Menitove J, Kagen L, et al. Leukocyte reduction and ultraviolet B irradiation of platelets to prevent alloimmunization and refractoriness to platelet transfusions. The Trial to Reduce Alloimmunization to Platelets Study Group. N Engl J Med. 1997;337(26): 1861-1869.

97. Seftel MD, Growe GH, Petraszko T, et al. Universal prestorage leukoreduction in Canada decreases platelet alloimmunization and refractoriness. Blood. 2004;103(1):333-339.

98. Bilgin YM, Brand A. Transfusion-related immunomodulation: a second hit in an inflammatory cascade? Vox Sang. 2008;95(4):261-271.
99. Vamvakas EC, Blajchman MA. Blood still kills: six strategies to further reduce allogeneic blood transfusion-related mortality. Transfus Med Rev. 2010;24(2):77-124.

100. Williamson LM, Stainsby D, Jones H, et al. The impact of universal leukodepletion of the blood supply on hemovigilance reports of posttransfusion purpura and transfusion-associated graft-versus-host disease. Transfusion. 2007;47(8):1455-1467.

101. Sparrow RL, Patton KA. Supernatant from stored red blood cell primes inflammatory cells: influence of prestorage white cell reduction. Transfusion. 2004;44(5):722-730.

102. Silliman CC, Ambruso DR, Boshkov LK. Transfusion-related acute lung injury. Blood. 2005;105(6):2266-2273.

103. Cervia JS, Wenz B, Ortolano GA. Leukocyte reduction's role in the attenuation of infection risks among transfusion recipients. Clin Infect Dis. 2007;45(8):1008-1013.

104. Gregori L, McCombie N, Palmer D, et al. Effectiveness of leucoreduction for removal of infectivity of transmissible spongiform encephalopathies from blood. Lancet. 2004;364(9433): 529-531.

105. Ludlam CA, Turner ML. Managing the risk of transmission of variant Creutzfeldt Jakob disease by blood products. Br J Haematol. 2006;132(1):13-24.

106. Davidson F, Lycett C, Jarvis LM, et al. Detection of HTLV-I and -II in Scottish blood donor samples and archive donations. Vox Sang. 2006;91(3):231-236.

107. Davison KL, Dow B, Barbara JA, Hewitt PE, Eglin R. The introduction of anti-HTLV testing of blood donations and the risk of transfusion-transmitted HTLV, UK: 2002-2006. Transfus Med. 2009; 19(1):24-34.

108. Rawal BD, Busch MP, Endow R, et al. Reduction of human immunodeficiency virus-infected cells from donor blood by leukocyte filtration. Transfusion. 1989;29(5):460-462.

109. Bruisten SM, Tersmette M, Wester MR, Vos AHV, Koppelman MH, Huisman JG. Efficiency of white cell filtration and a freeze-thaw procedure for removal of HIV-infected cells from blood. Transfusion. 1990;30(9):833-837.

110. Vamvakas EC. The case against universal white blood cell reduction. ISBT Science Series. 2006;1(1):64-72.

111. Brady MT, Milam JD, Anderson DC, et al. Use of deglycerolized red blood cells to prevent posttransfusion infection with cytomegalovirus in neonates. J Infect Dis. 1984;150(3):334-339.

112. Luban NL, Williams AE, MacDonald MG, Mikesell GT, Williams KM, Sacher RA. Low incidence of acquired cytomegalovirus infection in neonates transfused with washed red blood cells. Am J Dis Child. 1987;141(4):416-419.

113. Gilbert GL, Hayes K, Hudson IL, James J. Prevention of transfusionacquired cytomegalovirus infection in infants by blood filtration to remove leucocytes. Neonatal Cytomegalovirus Infection Study Group. Lancet. 1989;1(8649):1228-1231.

114. Eisenfeld L, Silver H, McLaughlin J, et al. Prevention of transfusionassociated cytomegalovirus infection in neonatal patients by the removal of white cells from blood. Transfusion. 1992;32(3):205-209.

115. Triulzi DJ, Dzik WH. Leukocyte-reduced blood components: laboratory and clinical aspects. In: Simon TL, Snyder EL, Solheim BG, Stowell CP, Strauss RG, Petrides M, editors. Rossi's Principles of Transfusion Medicine. Chichester, UK: Wiley-Blackwell; 2009: 228-246.

116. Kakaiya R, Aronson CA, Julleis J. Whole blood collection and component processing. In: Roback JD, Combs MR, Grossman BJ, Hillyer CD, editors. Technical Manual, 16th edition. Bethesda, MD: AABB; 2008:189-228.

117. Dumont LJ, Luka J, VandenBroekeT, Whitley P, Ambruso DR, Elfath MD. The effect of leukocyte-reduction method on the amount of human cytomegalovirus in blood products: a comparison of apheresis and filtration methods. Blood. 2001;97(11):3640-3647. 
118. VerdonckLF, de Graan-HentzenYC, DekkerAW, Mudde GC, de Gast GC. Cytomegalovirus seronegative platelets and leukocyte-poor red blood cells from random donors can prevent primary cytomegalovirus infection after bone marrow transplantation. Bone Marrow Transplant. 1987;2(1):73-78.

119. Murphy MF, Grint PCA, Hardiman AE, Lister TA, Waters AH. Use of leucocyte-poor blood components to prevent primary cytomegalovirus (CMV) infection in patients with acute leukaemia. Br J Haematol. 1988;70(2):253-254.

120. de Graan-Hentzen YC, Gratama JW, Mudde GC, et al. Prevention of primary cytomegalovirus infection in patients with hematologic malignancies by intensive white cell depletion of blood products. Transfusion. 1989;29(9):757-760.

121. van Prooijen HC, Visser JJ, van Oostendorp WR, de Gast GC, Verdonck LF. Prevention of primary transfusion-associated cytomegalovirus infection in bone marrow transplant recipients by the removal of white cells from blood components with high-affinity filters. Br J Haematol. 1994;87(1):144-147.

122. Bowden RA, Slichter SJ, Sayers MH, Mori M, Cays MJ, Meyers JD. Use of leukocyte-depleted platelets and cytomegalovirus-seronegative red blood cells for prevention of primary cytomegalovirus infection after marrow transplant. Blood. 1991;78(1):246-250.

123. Pamphilon DH, Foot ABM, Adeodu A, et al. Prophylaxis and prevention of CMV infection in BM allograft recipients: Leucodepleted platelets are equivalent to those from CMV seronegative donors. Bone Marrow Transplant. 1999;23(Suppl 1):S66.

124. Nichols WG, Price TH, Gooley T, Corey L, Boeckh M. Transfusiontransmitted cytomegalovirus infection after receipt of leukoreduced blood products. Blood. 2003;101(10):4195-4200.

125. Ljungman P, Larsson K, Kumlien G, et al. Leukocyte depleted, unscreened blood products give a low risk for CMV infection and disease in CMV seronegative allogeneic stem cell transplant recipients with seronegative stem cell donors. Scand J Infect Dis. 2002;34(5): 347-350.

126. Bowden RA, Slichter SJ, Sayers M, et al. A comparison of filtered leukocyte-reduced and cytomegalovirus (CMV) seronegative blood products for the prevention of transfusion-associated CMV Infection after marrow transplant. Blood. 1995;86(9):3598-3603.

127. James DJ, Sikotra S, Sivakumaran M, et al. The presence of free infectious cytomegalovirus (CMV) in the plasma of donated CMV-seropositive blood and platelets. Transfus Med. 1997;7(2): 123-126.
128. Vamvakas EC. Is white blood cell reduction equivalent to antibody screening in preventing transmission of cytomegalovirus by transfusion? A review of the literature and meta-analysis. Transfus Med Rev. 2005;19(3):181-199.

129. Ziemann M, Heuft HG, Frank K, Kraas S, Görg S, Hennig H. Window period donations during primary cytomegalovirus infection and risk of transfusion-transmitted infections. Transfusion. 2013;53(5): 1088-1094.

130. Furui Y, Satake M, Hoshi Y, Uchida S, Suzuki K, Tadokoro K. Cytomegalovirus (CMV) seroprevalence in Japanese blood donors and high detection frequency of CMV DNA in elderly donors. Transfusion. 2013;53(10):2190-2197.

131. Dollard SC, Roback JD, Gunthel C, et al. Measurements of human herpesvirus 8 viral load in blood before and after leukoreduction filtration. Transfusion. 2013;53(10):2164-2167.

132. Roback JD, Josephson CD. New insights for preventing transfusiontransmitted cytomegalovirus and other white blood cell-associated viral infections. Transfusion. 2013; 53(10):2112-2116.

133. Bryant BJ, Klein HG. Pathogen inactivation: the definitive safeguard for the blood supply. Arch Pathol Lab Med. 2007;131(5): 719-733.

134. Vamvakas EC, Blajchman MA. Transfusion-related mortality: the ongoing risks of allogeneic blood transfusion and the available strategies for their prevention. Blood. 2009;113(15):3406-3417.

135. Marschner S, Goodrich R. Pathogen Reduction Technology Treatment of Platelets, Plasma and Whole Blood Using Riboflavin and UV Light. Transfus Med Hemother. 2011;38(1):8-18.

136. Fast LD, DiLeone G, Marschner S. Inactivation of human white blood cells in platelet products after pathogen reduction technology treatment in comparison to gamma irradiation. Transfusion. 2011;51(7): 1397-1404.

137. van Rhenen D, Gulliksson H, Cazenave JP, et al; euroSPRITE trial. Transfusion of pooled buffy coat platelet components prepared with photochemical pathogen inactivation treatment: the euroSPRITE trial. Blood. 2003;101(6):2426-2433.

138. McCullough J, Vesole DH, Benjamin RJ, et al. Therapeutic efficacy and safety of platelets treated with a photochemical process for pathogen inactivation: the SPRINT Trial. Blood. 2004;104(5):1534-1541.

139. Schleiss MR. Cytomegalovirus vaccine development. Curr Top Microbiol Immunol. 2008;325:361-382.

140. Sung S, Schleiss MR. Update on the current status of cytomegalovirus vaccines. Expert Rev Vaccines. 2010;9(11):1303-1314.
International Journal of Clinical Transfusion Medicine

\section{Publish your work in this journal}

International Journal of Clinical Transfusion Medicine is an international, peer-reviewed, open access, online journal publishing clinicalexperimental, policy-making and evidence-based practices of all topics pertaining to clinical transfusion medicine. Original research, short reports, reviews, case reports and commentaries are invited.

\section{Dovepress}

The manuscript management system is completely online and includes a very quick and fair peer-review system, which is all easy to use. Visit http://www.dovepress.com/testimonials.php to read real quotes from published authors. 